\section{Breakup of last glacial deep stratification in the South Pacific}

\author{
Chandranath Basak, ${ }^{1 *} \dagger \ddagger$ Henning Fröllje,${ }^{1,2} \ddagger$ Frank Lamy, ${ }^{3}$ Rainer Gersonde, ${ }^{3}$ \\ Verena Benz, ${ }^{3}$ Robert F. Anderson, ${ }^{4}$ Mario Molina-Kescher, ${ }^{5}$ Katharina Pahnke ${ }^{1}$
}

\begin{abstract}
Stratification of the deep Southern Ocean during the Last Glacial Maximum is thought to have facilitated carbon storage and subsequent release during the deglaciation as stratification broke down, contributing to atmospheric $\mathrm{CO}_{2}$ rise. Here, we present neodymium isotope evidence from deep to abyssal waters in the South Pacific that confirms stratification of the deepwater column during the Last Glacial Maximum. The results indicate a glacial northward expansion of Ross Sea Bottom Water and a Southern Hemisphere climate trigger for the deglacial breakup of deep stratification. It highlights the important role of abyssal waters in sustaining a deep glacial carbon reservoir and Southern Hemisphere climate change as a prerequisite for the destabilization of the water column and hence the deglacial release of sequestered $\mathrm{CO}_{2}$ through upwelling.
\end{abstract}

T he Southern Ocean (SO) has long been recognized as a key player in regulating atmospheric $\mathrm{CO}_{2}$ variations and hence global climate based on the tight coupling between Southern Hemisphere (SH) temperatures and atmospheric $\mathrm{CO}_{2}$ concentrations (I). Nevertheless, the mechanisms involved are not fully understood. The most promising explanation includes changes of the biological pump and its interaction with ocean circulation in the SO, where $\mathrm{CO}_{2}$ sequestration and release occur because of the production of new and upwelling of old deep waters (2-4). The SO therefore acts as a component of ocean-atmosphere interactions that is sensitive to changes in climate and the stability of the water column. Evidence exists for a stratified deep SO during the Last Glacial Maximum (LGM) $(5,6)$, which led to diminished gas exchange as compared with that of today and the presence of radiocarbon-depleted deep waters in the South Pacific (7) overlying better ventilated bottom waters (7-9). With the onset of SH warming during the last deglaciation, which was approximately coincident with Heinrich Stadial 1 (HS1), the SO water column became destratified and well mixed, releasing sequestered $\mathrm{CO}_{2}$ to the atmosphere and contributing to the deglacial atmospheric $\mathrm{CO}_{2}$ rise (4-7). The proposed destratification mechanisms include southwardshifting westerlies and enhanced upwelling (5),

\footnotetext{
${ }^{1}$ Max Planck Research Group for Marine Isotope Geochemistry, Institute for Chemistry and Biology of the Marine Environment (ICBM), University of Oldenburg, Carl-von-Ossietzky-Strasse 9-11, 26129 Oldenburg, Germany. ${ }^{2}$ Department of Geosciences, University of Bremen, Klagenfurter Strasse 2-4, 28359 Bremen, Germany. ${ }^{3}$ Alfred Wegener Institute, Helmholtz Centre for Polar and Marine Research, Am Handelshafen 12, 27570 Bremerhaven, Germany. ${ }^{4}$ Lamont-Doherty Earth Observatory of Columbia University, 61 Route 9W. Palisades, NY 10964, USA. ${ }^{5}$ GEOMAR Helmholtz Centre for Ocean Research Kiel, Wischhofstraße 1-3, 24148 Kiel, Germany.

*Corresponding author. Email: cbasak@csub.edu †Present address: California State University, 9001 Stockdale Highway, Bakersfield, CA 93311, USA. ‡These authors contributed equally to this work.
}

as well as sea ice retreat, associated buoyancy flux changes, and increased mixing of northernand southern-sourced waters (10). Here, we show evidence for a sharp geochemical boundary between deep and bottom waters in the Pacific sector of the SO during the LGM. This deep stratification is defined by distinct neodymium (Nd) isotope signatures of the deep and abyssal waters during the LGM, in contrast to a homogeneous $\mathrm{Nd}$ isotopic composition of the deep to abyssal South Pacific today (11). We further suggest a role for SH climate in triggering the breakup of deep stratification, thus setting the stage for upwelling and release of sequestered carbon.

We used Nd isotopes $\left({ }^{143} \mathrm{Nd} /{ }^{144} \mathrm{Nd}\right.$, expressed as $\varepsilon_{\mathrm{Nd}}$ ) from fossil fish teeth and debris and

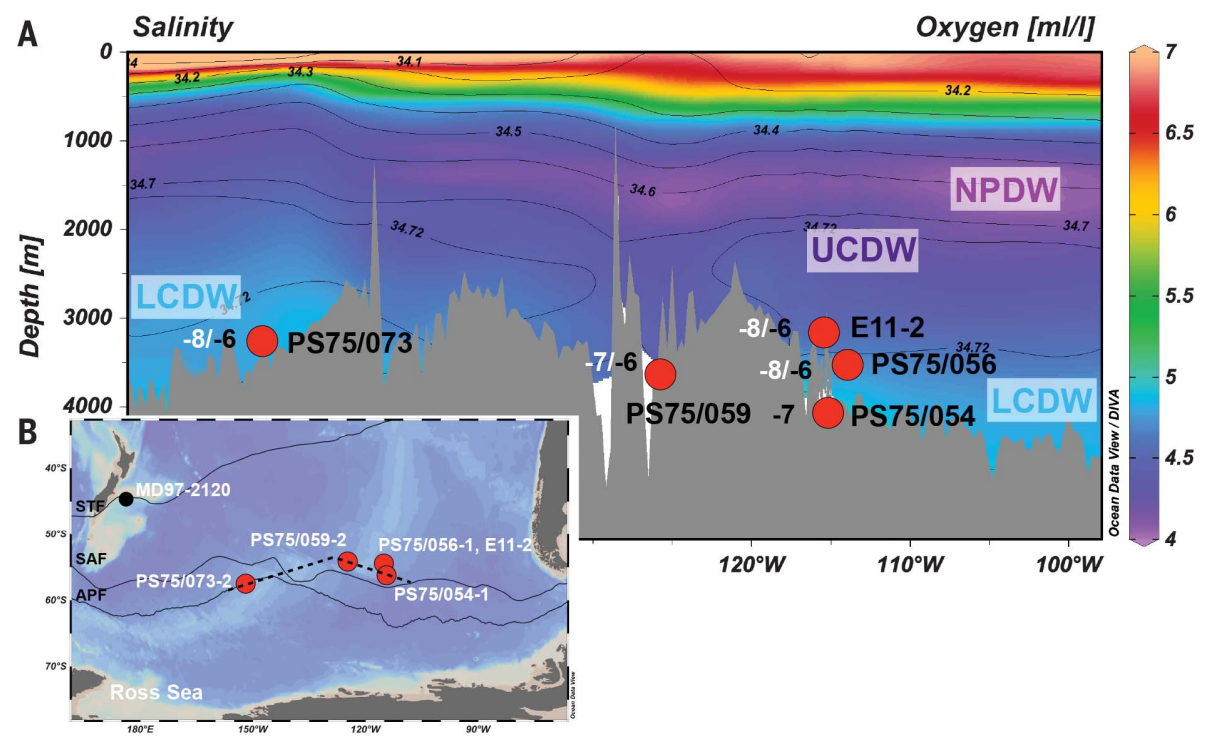

Fig. 1. Modern hydrography and core locations in the South Pacific. (A) Zonal section [along stippled line in (B)] of dissolved oxygen (color) (45) and salinity (contours) (46), with depth locations of studied cores, major deepwater masses, and modern (white) and LGM (black) $\varepsilon_{N d}$ values at each core site. (B) Core locations, including reference core MD97-2120, and major Antarctic fronts (47). APF, Antarctic Polar Front; SAF, Subantarctic Front; STF, Subtropical Front. 
well-dated core MD97-2120 (19, 20), except for PS75/054-1, which is tied to PS75/056-1 by using $\mathrm{x}$-ray fluorescence rubidium scans in both cores, a proxy for dust content (supplementary materials). The cores cover the depth range of modern lower to upper CDW (L/UCDW) and are therefore ideal for monitoring the deglacial evolution of the deep South Pacific water column structure (Fig. 1 and supplementary materials). Nd isotopes show late Holocene core-top values of -8.3 (PS75/ 073-2) and -7.2 to -7.7 (PS75/059-2, PS75/056-1, and E11-2), which is consistent with modern CDW, with slightly different contributions from NPDW and NADW related to the difference in depth and latitudinal position of the cores (Fig. 1 and fig. S3) (11). The deepest core (PS75/054-1) lacks Late Holocene sediments, but modern hydrography at the core site indicates the presence of LCDW (Fig. 1A and supplementary materials). This core is currently located close to the boundary of LCDW and RSBW (the South Pacific contribution to AABW). Considering that the temporal resolution of the core is low after HS1, with the observed changes only supported by individual data points, we restrict our discussion related to this core to the LGM and HS1.

During the LGM, the average $\varepsilon_{\mathrm{Nd}}$ at the deep sites was consistently at $\sim 6$ (Figs. 1A and 2, E to $\mathrm{H}$ ), suggesting that one homogeneous water mass occupied the deep South Pacific. By contrast, at abyssal depth, a more negative $\varepsilon_{\mathrm{Nd}}$ of $-7.5 \pm 0.2$ $(n=5)$ prevailed throughout the LGM and early deglaciation, suggesting reduced mixing between deep and abyssal waters and a northward expansion of RSBW ( $\varepsilon_{\mathrm{Nd}}=-7$ ) (Figs. 1A and 2D) (11). The deglaciation in the deep cores (PS75/056-1 and PS75/073-2) was marked by an $\varepsilon_{\mathrm{Nd}}$ decrease that started at the beginning of the first SH warming (W1) at 18.8 and 17.3 thousand years ago (ka ago), respectively (Fig. 3), which is coincident with HS1 in the Northern Hemisphere (NH) (Figs. 2 and 3) (21). A brief halt in the $\varepsilon_{\mathrm{Nd}}$ decrease in these cores occurred during the Antarctic Cold Reversal (ACR), and a second $\varepsilon_{\mathrm{Nd}}$ decrease was synchronous with the second SH warming starting at $\sim 12.8$ ka ago (W2) (Fig. 2). In the northernmost core PS75/059-2, LGM $\varepsilon_{\mathrm{Nd}}$ values of $\sim-6$ persisted until at least $13.4 \mathrm{ka}$ ago, followed by an $\varepsilon_{\mathrm{Nd}}$ decrease

Fig. 2. Evolution of the SO water column structure, NADW formation, and climate over the past $\mathbf{3 0 , 0 0 0}$ years. (A) Greenland ice core $\delta^{18} \mathrm{O}(48)$. (B) $\varepsilon_{\mathrm{Nd}}$ of western North Atlantic core GGC6 (22). (C) $\varepsilon_{\mathrm{Nd}}$ of South Atlantic cores RC11-83 (16) and MD07-3076 (17). (D to H) Fish teeth and planktic foraminifera $\varepsilon_{\mathrm{Nd}}$ of South Pacific cores (this study). Vertical error bars are propagated errors (supplementary materials).

(I) European Project for Ice Coring in Antarctica (EPICA) Dome C ice core $\delta D(49,50)$. (J) West Antarctic Ice Sheet (WAIS) ice core $\delta^{18} \mathrm{O}$ (51). (K) Opal fluxes from the South Atlantic (core TN057-13PC) representing SO upwelling (5). SH warming episodes W1 and W2 [after (21)] roughly correspond to $\mathrm{NH}$ cold phases HS1 and Younger Dryas.

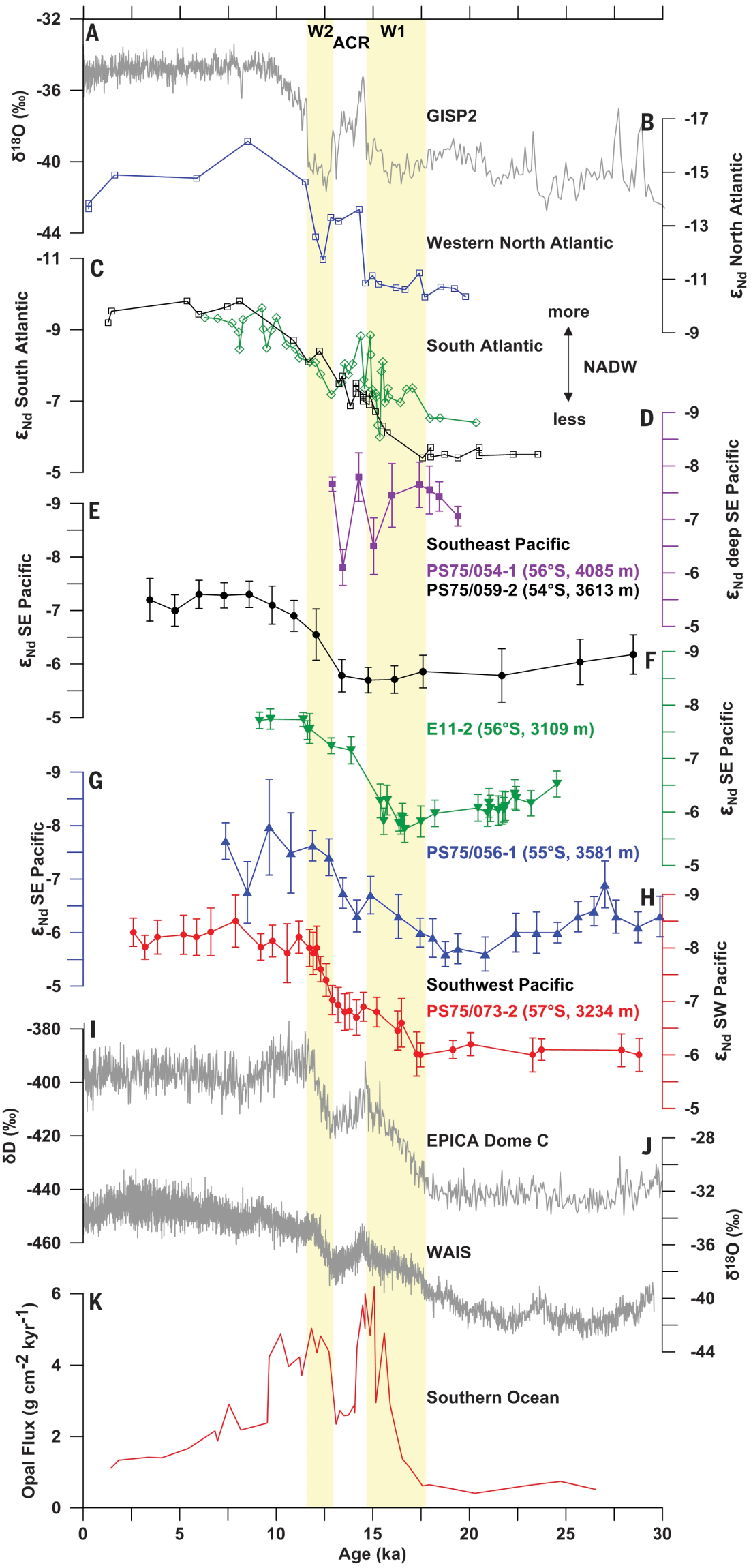




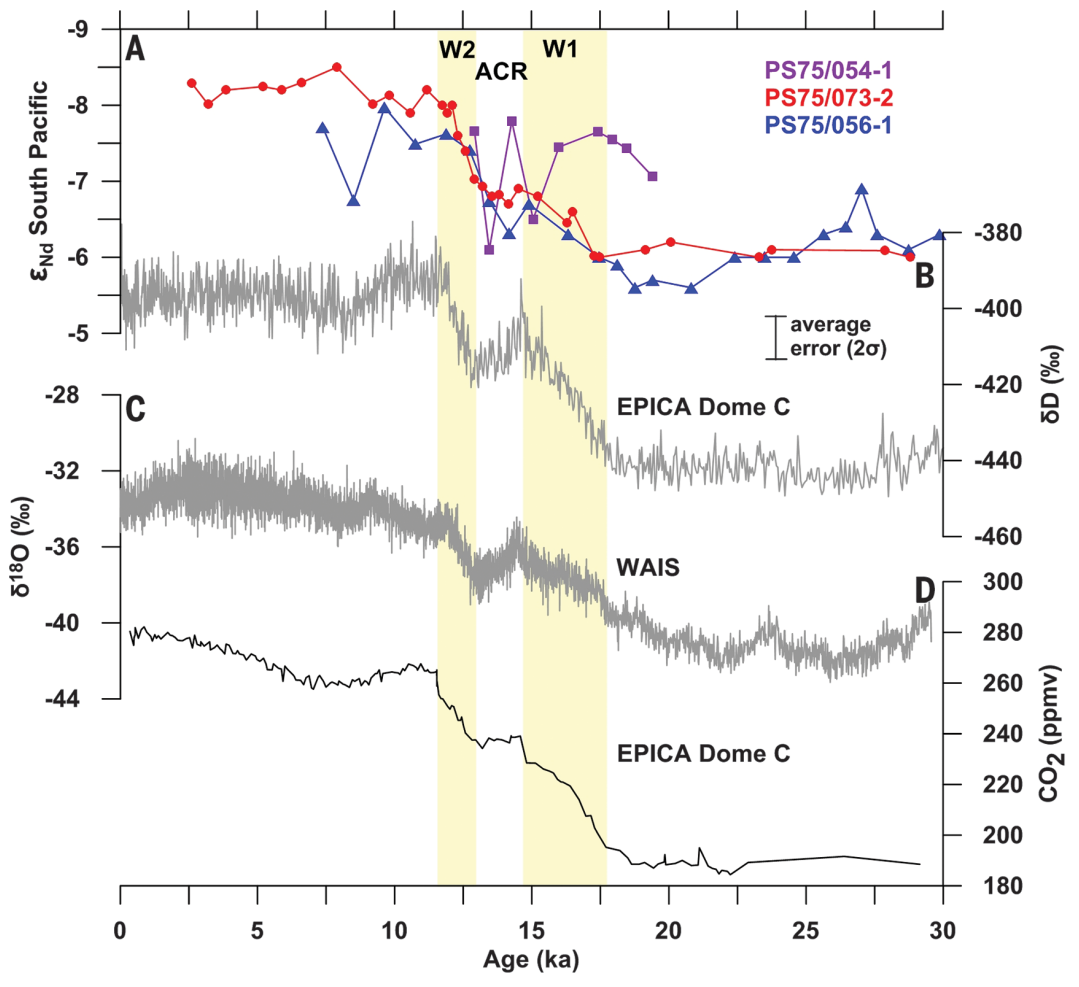

Fig. 3. Comparison of South Pacific $\varepsilon_{\text {Nd }}$ time series and Antarctic climate over the past 30,000 years. (A) Downcore $\varepsilon_{N d}$ records from deep South Pacific cores. (B) EPICA Dome C ice core $\delta \mathrm{D}(49,50)$. (C) $\delta^{18} \mathrm{O}$ record of WAIS ice core (51). (D) Atmospheric $\mathrm{CO}_{2}$ concentrations from EPICA Dome C ice core $(49,50,52)$.

during W2 that coincided with the second $\varepsilon_{\mathrm{Nd}}$ decrease in the other cores. This difference in timing is real and cannot be explained by age model uncertainties (supplementary materials). Similarly, the first $\varepsilon_{\mathrm{Nd}}$ decrease in core E11-2 started at mid-W1, with some delay relative to the deeper cores; the difference in timing is, however, close to the age model uncertainty.

The homogeneous LGM deepwater $\varepsilon_{\mathrm{Nd}}$ of $\sim-6$ in the South Pacific is in line with a reduced incorporation of unradiogenic NADW into SO water masses. This may be explained by reduced formation and southward export of NADW during the LGM $(22,23)$. In addition, despite continuous formation of North Atlantic Component Water (NACW) $(24,25)$, a decoupling of the upper (northern sourced) and lower (southern sourced) circulation cells in the Atlantic during the LGM (10) would also have prevented an incorporation of the North Atlantic signal into the SO. The slightly more radiogenic glacial $\varepsilon_{\mathrm{Nd}}$ in the South Pacific $\left(\varepsilon_{\mathrm{Nd}}=-6\right)$ relative to the South Atlantic $\left(\varepsilon_{\mathrm{Nd}}=-6.5\right.$ to -7.3$)(16,18)$ results from the higher influence of radiogenic Pacific deep water and/or less direct influence of NADW in the Pacific. The most radiogenic glacial South Atlantic $\varepsilon_{\mathrm{Nd}}$ of -5.5 (17) has previously been related to higher Pacific influence in the central southwest Atlantic (24). The distinct abyssal South Pacific LGM $\varepsilon_{\mathrm{Nd}}$ of -7.5 (PS75/054) differs from glacial CDW $\left(\varepsilon_{\mathrm{Nd}}=-6\right)$ and modern
NPDW $\left(\varepsilon_{\mathrm{Nd}}=-3.5\right)(14)$ but is similar to modern RSBW ( $\left.\varepsilon_{\mathrm{Nd}}=-7 \pm 0.5\right)(11)$.

Today, AABW is formed over the Antarctic shelves and spreads northward at abyssal depth. Outside the SO, abyssal water is largely represented by LCDW. For the LGM, it was suggested that AABW extended far into the North Atlantic as NADW shoaled $(22,23)$. That is, AABW changes have largely been explained on the basis of the dependent interplay between the upper and lower circulation cells in the Atlantic $(16,18,22-24)$. The exclusive history of AABW, however, is relatively unstudied. The eastern South Pacific is located at the far end of the NADW flow path, and our cores should therefore document the history of RSBW and CDW without being masked by direct influence of fluctuating NADW contributions. Moreover, NPDW formation can be considered constant during both the LGM and the Holocene, although there are reports of increased NPDW formation during HS1 (26). Changes in NPDW can thus be excluded as a possible agent controlling South Pacific abyssal water $\varepsilon_{\mathrm{Nd}}$ during the LGM and Holocene. Our observed glacial abyssal $\varepsilon_{\mathrm{Nd}}$ of -7.5 together with the $\varepsilon_{\mathrm{Nd}}$ contrast to overlying deep waters $\left(\varepsilon_{\mathrm{Nd}}=-6\right)$ therefore provide direct evidence for glacial northward expansion of RSBW and reduced mixing between the deep and bottom layer (Fig. 4). This is in line with previous suggestions of increased glacial presence of RSBW in the southwest Pacific (8) and increased glacial formation and export of AABW into the Pacific (27).

The glacial deep stratification inferred from different $\varepsilon_{\mathrm{Nd}}$ above and below $\sim 3500$ to $4000 \mathrm{~m}$ water depth is consistent with salinity and density reconstructions that show a clear separation between very high-density bottom water at $3600 \mathrm{~m}$ and lower-density water at $3200 \mathrm{~m}$ in the $\mathrm{SO}(28,29)$. This high density of SO bottom water during the LGM together with a reduced flow speed of the Antarctic Circumpolar Current (ACC) north of the Antarctic Polar Front (APF) (30) would have reduced diapycnal mixing at depths where mixing occurs today through interaction of abyssal current flow with bottom topography (31). A glacial northward expansion of extremely dense (29) RSBW and isolation from overlying deep water may have further stabilized the deepwater column in the South Pacific and hence facilitated efficient deepwater carbon storage $(7,17,32)$.

The deglacial deepwater $\varepsilon_{\mathrm{Nd}}$ decrease during W1 (HS1) is a pervasive feature of SO deepwater records (Fig. 2, $\mathrm{C}$ and $\mathrm{F}$ to $\mathrm{H}$ ) and has previously been associated with the resumption of NADW formation and incorporation of its unradiogenic $\varepsilon_{\mathrm{Nd}}$ into $\operatorname{CDW}(17,18,33)$. Yet, this initial $\varepsilon_{\mathrm{Nd}}$ decrease in all but one available record (18) from the SO predated NADW reinvigoration in the deep North Atlantic (Fig. 2) (22). That is, the observed SO-wide deglacial $\varepsilon_{\mathrm{Nd}}$ decrease cannot be explained by increased supply of unradiogenic NACW to the SO. The coincidence of the ubiquitous SO deepwater $\varepsilon_{\mathrm{Nd}}$ decrease with SH climate warming instead suggests a $\mathrm{SH} / \mathrm{SO}$ control. The high density of RSBW is acquired through brine rejection during sea ice formation in cold climates. SH warming will reduce sea ice formation and thus brine rejection, leading to a decrease in bottom water density (28). A weakening of the density contrast between deep and bottom waters together with increasing ACC strength (30), and hence enhanced flow over bottom topography, would have been conducive to vertical mixing at depth (31). The resulting destratification of the deep SO would lead to the observed deepwater $\varepsilon_{\mathrm{Nd}}$ decrease, concurrent abyssal water $\varepsilon_{\mathrm{Nd}}$ increase, and trend toward a geochemically homogeneous deep to abyssal SO during mid-deglaciation as a result of upward mixing of less radiogenic RSBW/AABW (Figs. 2 and 4). The Ross and Weddell Seas are two main sites of modern AABW formation, and the bottom waters formed there have distinct $\varepsilon_{\mathrm{Nd}}$ signatures of -7 and -9 , respectively $(11,12)$. These distinct signatures can explain the observed differences in the deglacial $\varepsilon_{\mathrm{Nd}}$ amplitudes in the South Pacific and South Atlantic during W1 (LGM to $15 \mathrm{ka}$ ago: $\sim 1 \varepsilon_{\mathrm{Nd}}$ and $\sim 2 \varepsilon_{\mathrm{Nd}}$ units, respectively) (Figs. $2 \mathrm{C}$ and 3 ) and the SOwide early deglacial $\varepsilon_{\mathrm{Nd}}$ decrease. Additionally, increasing incorporation of NACW (or Glacial North Atlantic Intermediate Water above $2 \mathrm{~km}$ ) (34) into SO deep waters through increased mixing between the upper (NACW-bearing) and lower [Southern Component Water (SCW)-bearing] circulation cells (10) could have also decreased 

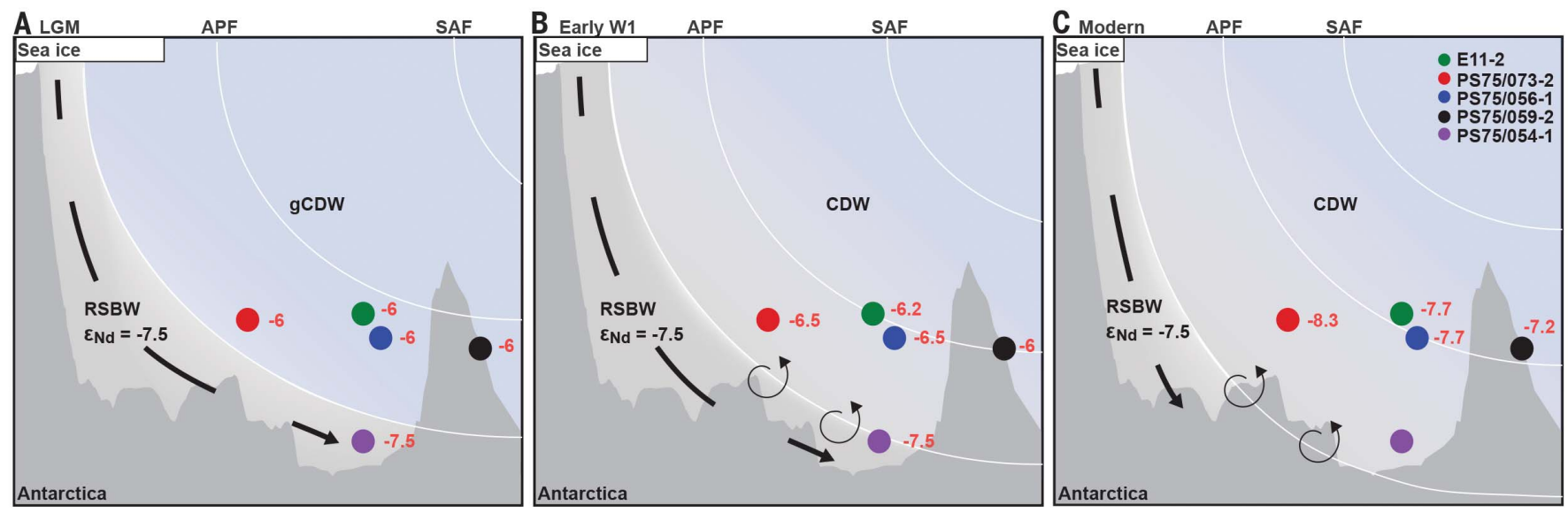

Fig. 4. Schematic illustration of the South Pacific water column structure for the LGM, deglaciation, and Holocene. (A) LGM: NADW input to SO strongly reduced/absent. RSBW $\left(\varepsilon_{\mathrm{Nd}}=-7.5\right)$ extends further north than today and is isolated from overlying glacial CDW (gCDW) $\left(\varepsilon_{N d}=-6\right)$. (B) Early deglacial: SO warming during W1 leads to destratification at depth and increased mixing of RSBW into CDW, changing the $\mathrm{CDW} \varepsilon_{\mathrm{Nd}}$ to $\sim-6.5$. Atlantic contribution is still attenuated Core PS75/059-2 is isolated from early deglacial SO processes. (C) Holocene and modern: Strengthening of the Atlantic Meridional Overturning Circulation and SO warming lead to incorporation of NADW into CDW (10), changing its $\varepsilon_{N d}$ signature to -8 . RSBW does not extend to deepest site (PS75/054-1). the $\varepsilon_{\mathrm{Nd}}$ of CDW. However, given the physical constraint of the Drake Passage $\left(\sim 57^{\circ}\right.$ to $61^{\circ} \mathrm{S}$, sill depth $\sim 2000 \mathrm{~m}$ ), which prevents a meridional net geostrophic flow across this latitude band for waters shallower than the sill depth $(35,36)$, we consider this mechanism less important.

The delayed response to $\mathrm{W} 1$ in the northernmost core PS75/059-2 (at $12.1 \mathrm{ka}$ ago) is robust and outside the age model uncertainty, whereas the smaller delay in the shallowest core E11-2 (change at 15.6 ka ago) is close to the age model uncertainty (supplementary materials). Under modern conditions, core PS75/059-2 exhibits stronger NPDW influence than the other core sites that are dominantly influenced by LCDW (Fig. 1) (11). The $\varepsilon_{\mathrm{Nd}}$ decrease seen in LCDW-influenced cores during W1 may hence not have affected PS75/059-2.

On the basis of reduced radiocarbon ventilation ages in the deep Cape Basin $\left(41^{\circ} \mathrm{S}\right)(37)$ during the Bølling-Allerød (B-A; approximately at the same time as the ACR), Barker et al. (37) argued for strongly enhanced southward flow of NADW. A northern source of this well-ventilated water is, however, not confirmed by Nd isotope results and was instead suggested to indicate ventilation by SCW (17). Similarly, we see no evidence for increased incorporation of NACW into CDW during the ACR in the South Pacific, nor is this seen in any other independently dated SO $\varepsilon_{\mathrm{Nd}}$ record (Fig. 2) $(17,38)$. A change in the North Atlantic $\varepsilon_{\mathrm{Nd}}$ end member toward more radiogenic values exclusively during the B-A/ACR period that could explain the lacking $\varepsilon_{\mathrm{Nd}}$ decrease at this time is unlikely. Such an end member $\varepsilon_{\mathrm{Nd}}$ change would be at odds with existing $\varepsilon_{\mathrm{Nd}}$ records in the deep North Atlantic that show unradiogenic $\varepsilon_{\mathrm{Nd}}$ during the $\mathrm{B}-\mathrm{A}(18,22)$ along with evidence for the long-term stability of the North Atlantic $\varepsilon_{\mathrm{Nd}}$ end member $(39,40)$. Instead, ${ }^{14} \mathrm{C}$ based evidence suggests that the deep North and South Atlantic were equally well ventilated during the ACR (41), indicating that the SO cannot have been exclusively ventilated by NADW. We suggest that although the ACR was a time of active NADW formation, making it quite different from the LGM in the NH, the ACR boundary conditions in the SH were akin to glacials, albeit less pronounced. Thus, similar to glacials, NADW incorporation into the SO during the ACR would have been restricted in response to reduced mixing between the NACW and SCW cells in the Atlantic $(10,32)$. This may have been promoted by northward-shifted westerlies similar to those of the LGM (42) in response to southern cooling, hampering the southward pull of NADW (35). With the onset of W2, mixing between the cells increased because of SH warming and sea ice retreat (10), a southward shift of the westerlies, and resulting increase in NADW southward pull (43), leading to the final incorporation of NACW into CDW despite reduced NADW formation at this time (the Younger Dryas stadial) (22). That is, $\mathrm{SH}$ processes initialized the establishment of modern conditions with NACW being mixed into $\mathrm{CDW}$, explaining the second $\varepsilon_{\mathrm{Nd}}$ decrease in the deep South Pacific.

Although a high-density contrast between deep and abyssal waters has been suggested on the basis of porewater chloride measurements (29), clear evidence of deep-abyssal stratification in the SO has been elusive. Our results show that RSBW expanded during the LGM, occupying the abyssal South Pacific to at least $\sim 4000$ m water depth, and was sharply separated from overlying deep water (Fig. 4). This may have further stabilized a stratified deep ocean, a scenario conducive to carbon accumulation in deep waters. The timing of W1 in the SH is well synchronized with deep-abyssal destratification indicated by a decrease in SO deepwater $\varepsilon_{\mathrm{Nd}}$ (trend toward $\varepsilon_{\mathrm{Nd}}$ homogenization) and also suggested on the basis of carbon isotopes (44). At the same time, a wind- driven upwelling pulse occurred in the SO that was suggested to have released old carbon stored in the deep SO to the atmosphere (Fig. 2) (5). However, an additional prerequisite for the initial deglacial $\mathrm{CO}_{2}$ release is the breakup of stratification in the deep-abyssal SO. Our data now provide evidence that this deep-abyssal destratification occurred in response to the initial deglacial SH warming. Thus, both deep vertical mixing and wind-driven upwelling were instrumental in the release of accumulated carbon from the deep SO to the atmosphere during Termination 1.

\section{REFERENCES AND NOTES}

1. F. Parrenin et al., Science 339, 1060-1063 (2013).

2. D. M. Sigman, E. A. Boyle, Nature 407, 859-869 (2000).

3. D. M. Sigman, M. P. Hain, G. H. Haug, Nature $466,47-55$ (2010)

4. A. Abelmann et al., Nat. Commun. 6, 8136 (2015)

5. R. F. Anderson et al., Science 323, 1443-1448 (2009).

6. A. Burke, L. F. Robinson, Science 335, 557-561 (2012).

7. T. A. Ronge et al., Nat. Commun. 7, 11487 (2016).

8. I. N. McCave, L. Carter, I. R. Hall, Quat. Sci. Rev. 27, 1886-1908 (2008)

9. E. L. Sikes, M. S. Cook, T. P. Guilderson, Earth Planet. Sci. Lett. 438, 130-138 (2016)

10. R. Ferrari et al., Proc. Natl. Acad. Sci. U.S.A. 111, 8753-8758 (2014)

11. C. Basak, K. Pahnke, M. Frank, F. Lamy, R. Gersonde, Earth Planet. Sci. Lett. 419, 211-221 (2015).

12. T. Stichel, M. Frank, J. Rickli, B. A. Haley, Earth Planet. Sci. Lett. 317-318, 282-294 (2012)

13. F. Lacan, C. Jeandel, Geochem. Geophys. Geosyst. 6, 012008 (2005)

14. H. Fröllje et al., Geochim. Cosmochim. Acta 189, 110-131 (2016)

15. L. D. Pena, S. L. Goldstein, Science 345, 318-322 (2014)

16. A. M. Piotrowski, S. L. Goldstein, S. R. Hemming, R. G. Fairbanks, Earth Planet. Sci. Lett. 225, 205-220 (2004)

17. L. C. Skinner et al., Geology 41, 667-670 (2013).

18. J. Lippold et al., Earth Planet. Sci. Lett. 445, 68-78 (2016).

19. K. Pahnke, R. Zahn, H. Elderfield, M. Schulz, Science 301 948-952 (2003)

20. K. Pahnke, R. Zahn, Science 307, 1741-1746 (2005) 
21. G. Siani et al., Nat. Commun. 4, 2758 (2013)

22. N. L. Roberts, A. M. Piotrowski, J. F. McManus, L. D. Keigwin, Science 327, 75-78 (2010)

23. W. B. Curry, D. W. Oppo, Paleoceanography 20, PA1017 (2005)

24. J. N. W. Howe et al., Nat. Commun. 7, 11765 (2016).

25. L. D. Keigwin, S. A. Swift, Proc. Natl. Acad. Sci. U.S.A. 114, 2831-2835 (2017).

26. J. W. B. Rae et al., Paleoceanography 29, 645-667 (2014).

27. I. R. Hall, I. N. McCave, N. J. Shackleton, G. P. Weedon, S. E. Harris, Nature 412, 809-812 (2001).

28. J. F. Adkins, Paleoceanography 28, 539-561 (2013).

29. J. F. Adkins, K. McIntyre, D. P. Schrag, Science 298, 1769-1773 (2002).

30. F. Lamy et al., Proc. Natl. Acad. Sci. U.S.A. 112, 13496-13501 (2015).

31. M. Nikurashin, R. Ferrari, Geophys. Res. Lett. 40, 3133-3137 (2013).

32. L. C. Skinner, S. Fallon, C. Waelbroeck, E. Michel, S. Barker, Science 328, 1147-1151 (2010).

33. A. M. Piotrowski, S. L. Goldstein, S. R. Hemming, R. G. Fairbanks, Science 307, 1933-1938 (2005)

34. J. Lynch-Stieglitz et al., Science 316, 66-69 (2007).

35. J. R. Toggweiler, B. Samuels, Deep Sea Res. Part I Oceanogr. Res. Pap. 42, 477-500 (1995)

36. L. Talley, Oceanography (Wash. D.C.) 26, 80-97 (2013).

37. S. Barker, G. Knorr, M. J. Vautravers, P. Diz, L. C. Skinner, Nat. Geosci. 3, 567-571 (2010).
38. A. M. Piotrowski et al., Earth Planet. Sci. Lett. 357-358, 289-297 (2012).

39. T. van de Flierdt, L. F. Robinson, J. F. Adkins, S. R. Hemming S. L. Goldstein, Paleoceanography 21, PA4102 (2006).

40. G. L. Foster, D. Vance, J. Prytulak, Geology 35, 37-40 (2007).

41. L. C. Skinner, C. Waelbroeck, A. E. Scrivner, S. J. Fallon Proc. Natl. Acad. Sci. U.S.A. 111, 5480-5484 (2014).

42. F. Lamy, D. Hebbeln, G. Wefer, Quat. Res. 51, 83-93 (1999).

43. J. R. Toggweiler, J. L. Russell, S. R. Carson, Paleoceanography 21. PA2005 (2006)

44. E. L. Sikes, A. C. Elmore, K. A. Allen, M. S. Cook, T. P. Guilderson, Earth Planet. Sci. Lett. 456, 87-97 (2016).

45. H. E. Garcia et al., World Ocean Atlas 2009, NOAA Atlas No. NESDros. Inf. Serv. 70 (NOAA, 2010).

46. J. I. Antonov et al., World Ocean Atlas 2009, NOAA Atlas No. NESDros. Inf. Serv. 69 (NOAA, 2010).

47. A. H. Orsi, T. Whitworth III, W. D. Nowlin Jr., Deep Sea Res. Part I Oceanogr. Res. Pap. 42, 641-673 (1995).

48. P. Grootes, M. Stuiver, J. Geophys. Res. 102, 26455-26470 (1997)

49. J. Jouzel et al., Science 317, 793-796 (2007)

50. D. Veres et al., Clim. Past 9, 1733-1748 (2013).

51. WAIS Divide Project Members, Nature 500, 440-444 (2013)

52. E. Monnin et al., Science 291, 112-114 (2001).

\section{ACKNOWLEDGMENTS}

Data presented in this study are available in the supplementary materials and on Pangaea under http://doi.pangaea.de/10.1594/ PANGAEA.858969. We thank the scientific party, captain, and crew of R/V Polarstern cruise ANT-XXVI/2. We thank M. Schulz and $P$. Böning from the Max Planck Research Group for Marine Isotope Geochemistry for help with labwork. We are grateful to J. Ullermann (Alfred Wegener Institute) for measuring benthic $\delta^{18} 0$ data that we used for age model construction of cores PS75/059-2 and PS75/056-1. We also thank three anonymous reviewers for their thoughtful comments. Financial support for this study came from the National Science Foundation (NSF) under grant OCE-09-35115 to K.P., ICBM, and the Max Planck Institute for Marine Microbiology.

SUPPLEMENTARY MATERIALS

www.sciencemag.org/content/359/6378/900/suppl/DC1

Materials and Methods

Supplementary Text

Figs. S1 to S5

Tables S1 to S4

References (53-91)

29 June 2017; accepted 10 January 2018

10.1126/science.aao2473 


\section{Science}

\section{Breakup of last glacial deep stratification in the South Pacific}

Chandranath Basak, Henning Fröllje, Frank Lamy, Rainer Gersonde, Verena Benz, Robert F. Anderson, Mario Molina-Kescher and Katharina Pahnke

Science 359 (6378), 900-904.

DOI: $10.1126 /$ science.aao2473

\section{$\mathrm{CO}_{2}$ escaped from the deep}

Why did the concentration of atmospheric carbon dioxide rise so much and so quickly during the last deglaciation? Evidence has begun to accumulate suggesting that old, carbon-rich water accumulated at depth in the Southern Ocean, which then released its charge when Southern Ocean stratification broke down as the climate there warmed. Basak et al. present measurements of neodymium isotopes that clearly show that the deepwater column of the glacial southern South Pacific was stratified, just as would be necessary for the accumulation of old, carbon-rich water. Their data also show that North Atlantic processes were not the dominant control on Southern Ocean water-mass structure during that interval, as has been thought.

Science, this issue p. 900

ARTICLE TOOLS

SUPPLEMENTARY

MATERIALS

REFERENCES

PERMISSIONS http://science.sciencemag.org/content/359/6378/900

http://science.sciencemag.org/content/suppl/2018/02/21/359.6378.900.DC1

This article cites 86 articles, 21 of which you can access for free http://science.sciencemag.org/content/359/6378/900\#BIBL

http://www.sciencemag.org/help/reprints-and-permissions

Use of this article is subject to the Terms of Service

Science (print ISSN 0036-8075; online ISSN 1095-9203) is published by the American Association for the Advancement of Science, 1200 New York Avenue NW, Washington, DC 20005. 2017 (C) The Authors, some rights reserved; exclusive licensee American Association for the Advancement of Science. No claim to original U.S. Government Works. The title Science is a registered trademark of AAAS. 